JEL: O15, Q01, R23

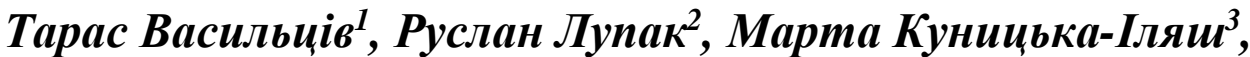 \\ Ольга Левицька ${ }^{1}$, Ольга Мульска ${ }^{1}$
}

'ДУ “Інститут регіональних досліджень ім. М. І. Долішнього НАН Украӥни” ${ }^{2}$ Львівський торговельно-економічний університет $3^{3}$ Львівський національний університет ветеринарної медицини та біотехнологій імені С. 3. Гжицького

Україна

\title{
ІНСТРУМЕНТИ РЕГІОНАЛЬНОЇ ПОЛІТИКИ ЗБЕРЕЖЕННЯ ЛЮДСБКОГО РЕСУРСУ ЗАСОБАМИ РЕГУЛЮВАННЯ ЗОВНІШНЬОЇ МІГРАЦІї МОЛОДІ СІЛЬСЬКИХ ТЕРИТОРІЙ КАРПАТСЬКОГО РЕГІОНУ ${ }^{1}$
}

Мета. Метою статті $\epsilon$ ідентифікація та аналіз негативних тенденцій, обтрунтування практичних рекомендацій щзодо удосконалення регіональної політики забезпечення збереження людського ресурсу засобами регулювання зовнішньої міграції молоді сільських територій Карпатського регіону Украӥни.

Методологія / методика / підхід. Методологічною основою дослідження стали загальнонаукові (графічний, структурний аналіз) та спеціальні (сочіологічний, інтегральне оцінювання, кореляційний аналіз) методи наукового пізнання. Соціологічне дослідження проведено ДУ “Інститут регіональних досліджень імені М. І. Долішнього НАН України”) у вересні-жовтні 2019 р. Об’єкт дослідження - студенти випускних курсів закладів вищої освіти, закладів загальної професійно-технічної освіти та учні випускних класів закладів загальної середньої освіти Карпатського регіону (1200 осіб). Авторський підхід до побудови інтегрального індексу середовища міграчійної активності населення передбачав реалізацію алгоритму, базисом якого виступало нормування показників (стимуляторів $i$ дестимуляторів), визначення ваг показників $і$ груп показників за допомогою побудови матриці корелячійних порівнянь, розрахунок багатовимірних величин у формі зважених групових індексів.

Результати. У статті із застосуванням соиіологічного дослідження виявлено характеристики зовнішньої міграційної активності молоді сільських територій Карпатського регіону України. Зроблено висновки щэодо проблемних аспектів міграції молоді та ї̈ впливу на розвиток сільських територій. Розраховано інтегральні індекси “виштовхування” населення України та Львівської області, щзо дозволило констатувати вищий рівень «агресивності» середовища для мігращії населення в Карпатському регіоні в порівнянні із середнім у країні. Обгрунтовано рекомендації щзодо інструментів регулювання міграчії молоді на сільських територіях для збереження людського потенціалу їхнього розвитку.

Оригінальність / наукова новизна. Розроблено нову методику розрахунку

${ }^{1}$ Дослідження виконано в рамках науково-дослідної теми «Міграційна активність населення Карпатського регіону» (ДУ «Інститут регіональних досліджень імені М. І. Долішнього НАН України», № держреєстрації 0119U002010, 2019-2021 pp.). 
інтегрального індекса середовища міграџійної активності населення (за п'ятьма групами показників: демографічна стабільність і стан здоров'я населення; охоплення населення освітніми послугами; стан ринку праці та зайнятості; рівень життя населення; економічний розвиток країни), а також удосконалено підхід до оцінки взаємозв'язку середовища "виштовхування" та міграџійної активності населення.

Практична цінність / значущість. Обгрунтовано інструменти регіональної політики забезпечення збереження людського ресурсу засобами регулювання зовнішньої міграції молоді сільських територій (за групами: організаційні, економічні, інституційні) для їх впровадження регіональними органами влади.

Ключові слова: розвиток сільських територій, збереження людського ресурсу, мігращійна активність молоді, регіональна політика, інструменти регулювання, Україна.

\section{Taras Vasyltsiv ${ }^{1}$, Ruslan Lupak ${ }^{2}$, Marta Kunytska-Iliash, Olha Levytska ${ }^{1}$, Olha Mulska}

${ }^{1}$ State Institution "Dolishniy Institute of Regional Research of the National Academy of Sciences of Ukraine"

${ }^{2}$ Lviv University of Trade and Economics

${ }^{3}$ Stepan Gzhytskyi National University of Veterinary Medicine and Biotechnologies Lviv

\section{INSTRUMENTS OF REGIONAL POLICY FOR HUMAN RESOURCES CONSERVATION BY MEANS OF REGULATION OF EXTERNAL YOUTH MIGRATION OF RURAL TERRITORIES OF THE CARPATHIAN REGION ${ }^{2}$}

Purpose. The aim of the article was to identify and analyze negative trends, substantiate practical recommendations for improving regional policy for preserving human resources by regulating the external migration of young people from rural territories of the Carpathian region in Ukraine.

Methodology / approach. The methodological basis of the study involved general scientific (graphic, structural analysis) and special (sociological, integral and correlation analysis) methods of research. Sociological survey was conducted by the SI "Dolishniy Institute of Regional Research of the National Academy of Sciences of Ukraine") in September-October 2019. The survey was focused on the higher educational institutions, vocational schools and general secondary schools graduate students from the Carpathian Region (1200 people). The author's approach to constructing an integral index of the migration activity environment involved the implementation of an algorithm based on the normalization of indicators (stimulators and de-stimulators), determination of the weights of indicators and groups of indicators by constructing a correlation matrix, calculation of multidimensional values in the form of weighted group indices.

Results. In the article, due to sociological research, characteristics of external migration activity of young people from rural areas of the Carpathian Region in Ukraine were analyzed. Conclusions were based on the problematic aspects of youth migration and its impact on the further development of rural areas. The integral indices of push-factors determining population migration

${ }^{2}$ The research has been conducted within the framework of Applied Research "Migration Activity of the Population of the Carpathian Region" (SI "Dolishniy Institute of Regional Research of the National Academy of Sciences of Ukraine", Reg. No. 0119U002010, period: 2019-2021). 
in Ukraine and Lviv Region were calculated, which allowed stating a higher level of "aggressiveness" of the population migration environment in the Carpathian Region compared to the average in the country. Recommendations on the instruments for regulating migration of young people from rural areas to preserve human potential for their development were substantiated.

Originality / scientific novelty. A new methodology for calculating the integral index of the environment of population migration activity was developed (using five groups of indicators: demographic stability and health status; population enrolment in education; labour market and employment conditions; living standards; economic development), as well as approach to evaluation of the relationship between the push-environment and migration activity of population was improved.

Practical value / implications. policy instruments for conserving human resources by regulating the external migration of young people from rural areas (by organizational, economic and institutional groups) were substantiated for their implementation by regional authorities.

Key words: rural development, human resource preservation, youth migration activity, regional policy, regulatory instruments, Ukraine.

Постановка проблеми. Регіональні економіки західних областей України розвиваються в умовах впливу чинників глобального, національного та регіонального характеру. 3 одного боку, на тлі повільних темпів розвитку внутрішнього виробництва, нової спеціалізації ринків, поділу праці усе гостріше постають проблеми дефіциту професійних кадрів. 3 іншого, українська робоча сила надає перевагу пошуку місця праці в більш заможних суспільствах, “оголюючи” через міграцію цілі сектори економіки у власній державі. Особливо критичними для національних інтересів $є$ втрати людського потенціалу молоді.

Рівень міграційної активності населення областей Карпатського регіону $є$ одним із найвищих у країні, що, крім іншого, пов'язано з його геополітичним розташуванням, а також зі зміною вектора трудової міграційної активності населення країни в напрямі країн Свропейського Союзу.

За результатами опитування 3 проблем зовнішньої трудової міграції Державної служби статистики України, мешканці західного регіону країни традиційно більше беруть участь у трудових міграціях і їхня частка становить близько 70,0\%; більшість мігрантів, які прямують у всі без винятку країни призначення, походять із західного регіону (73,7 \% у Польщі, 95,2 \% у Чеській Республіці, 54,2 \% у Португалії, 57,4\% у Російській Федерації); наміри українців щодо того, аби найближчого року поїхати за кордон на тимчасові заробітки, в західних областях України були одними з найвищих $(30,6 \%$, тоді як ствердну відповідь “ні” дали лише 19,4 \% опитаних) [1].

У структурі зовнішніх міграцій значно переважає населення сільських територій, що особливо негативно в контексті подальшого погіршення рівня їхнього соціально-економічного розвитку та зростання депресивності. Зовнішні міграційні процеси населення сільських територій Карпатського регіону набувають дедалі більш загрозливих масштабів, призводячи до значних втрат людського потенціалу, руйнування родин, депопуляції сільських територій i малих міст, формування працедефіцитної кон'юнктури та диспропорцій на ринку праці. 


\section{Agricultural and Resource Economics: International Scientific E-Journal}

http://are-journal.com

Останнім часом спостерігається зміна соціально-демографічної структури міграційних потоків, зокрема збільшується частка осіб молодого віку як у процесах зовнішньої трудової, так й освітньої міграції. Частка зовнішніх трудових мігрантів з України у віці 15-35 років у 2015-2019 рр. становила $47,2 \%$ для чоловіків та $26,9 \%$ для жінок; високою залишалася й частка населення у віці 15-35 років у структурі українських зовнішніх трудових мігрантів у країнах із найвищими обсягами трудової міграції населення 3 України, зокрема в Польщі (46,4 \%), в Угорщині (62,6 \%), у Чеській Республіці $(45,6 \%)$ [1]. Обсяги освітньої міграції молоді сільських територій областей Карпатського регіону за 2000-2019 рр. зросли більше ніж у 4 рази, а частка осіб у віці до 35 років у віковій структурі мігрантів досягла 40,0 \% [2]. Посилюються і настрої української молоді щодо навчання за кордоном. Наприклад, за даними дослідження МІОК, дві третини студентів НУ “Львівська політехніка" хотіли б навчатися за кордоном та близько 16,0 \% із них оцінює таку можливість як реальну. Серед найбільш бажаних для навчання країн студенти назвали Польщу (67,8 \%), Німеччину, Велику Британію, США [3]. Зростають і налаштування щодо подальшого працевлаштування українських студентів за кордоном. Так, найбільша чисельність студентів з України навчається в Польщі (близько 35 тис. осіб), при цьому, згідно 3 даними дослідження аналітичного центру CEDOS, чіткий намір до повернення на батьківщину після завершення навчання має лише близько 6,0\% [4].

Зростає інтенсивність інтелектуальної міграції, що посилює загрози демографічній, інтелектуальній, соціальній та іншим компонентам безпеки сільських територій західних регіонів та країни в цілому.

Аналіз останніх досліджень і публікацій. Проблеми функціонування та розвитку сільських територій, у т. ч. у фокусі їх ресурсного забезпечення, достатньо комплексно проаналізовані В. Бойком [5] та О. Іляш [6]. Результати досліджень цих авторів висвітлюють загальні сучасні передумови, тенденції, а також чинники розвитку сільських територій. Проте, більш глибоко аспекти людського ресурсу з прицілом на забезпечення економічної безпеки сільських територій розглядаються В. Бойком, П. Оліщук [7], Y. Woo, E. Kim [8].

Для забезпечення сталого розвитку сільських територій важливе значення мають усі компоненти їх потенціалу - економічний, соціальний, ресурсний та ін. Проте, з поміж них визначальне значення належить чинникам людського капіталу та людського ресурсу. До таких висновків доходять A. Wenham [9], М. Плотнікова [10], О. Бородіна, O. Rykobskaagro [11]

Власне, якість життя на сільських територіях значною мірою визначає поведінку населення, зокрема, з однієї сторони, щодо зайнятості й економічної активності, бажання проживати й робити свій внесок у розвиток цих територій; 3 іншої, в разі незадоволення рівнем якості життя та рівнем якості трудового життя, - до прийняття рішень про внутрішню чи зовнішню міграцію. Це висвітлено в працях S. Ayhana, K. Gatskova, H. Lehmann [12], S. Bauernschuster, O. Falck, S. Heblich, J. Suedekum, A. Lameli [13], A. Danzer, B. Dietz [14], 
N. Gheitarani, S. El-Sayed, S. Cloutier, M. Budruk, L. Gibbons, M. Khanian [15].

Для стримування міграційних процесів чи, навпаки, використання міграційного потенціалу в цілях збереження людського ресурсу та забезпечення покращення соціально-економічного розвитку сільських територій розробляються державні та регіональні програми, інформаційною основою яких слугують результати моделювання міграційних процесів, розроблені О. Левицькою, О. Мульскою, У. Іванюк, М. Куницькою-Іляш, Т. Васильцівим, Р. Лупаком [16]. При цьому, більш глибоко ці процеси досліджені в публікації Т. Васильціва, Р. Лупака, М. Куницької-Іляш [17], де моделюється вплив міграційних процесів на соціальну безпеку територій.

Достатньо детально питання формування ефективної державної політики регулювання міграційних процесів безпосередньо молоді та на сільських територіях аналізуються Т. Васильцівим, Р. Лупаком, О. Левицькою [18], Р.A. Rosvall [19], A. Wolfe, L. Black, H. Welser [20], R. Nugin [21].

Проблемами регіональної міграції та дослідженням впливу міграційних процесів на соціально-економічний розвиток територій активно займається Львівська школа регіоналістики [22-23].

Разом із тим, міграція набуває нових особливостей, у т. ч. у зв'язку із закономірними еволюціями безпосередньо сільських територій і їхнім впливом на соціально-економічний розвиток країни. Відтак, актуалізується потреба в більш грунтовному дослідженні та обгрунтуванні нових інструментів регіональної політики забезпечення збереження людського ресурсу засобами регулювання зовнішньої міграції молоді сільських територій.

Метою статті $\epsilon$ аналіз та ідентифікація негативних тенденцій, обгрунтування практичних рекомендацій щодо удосконалення регіональної політики забезпечення збереження людського ресурсу засобами регулювання зовнішньої міграції молоді сільських територій Карпатського регіону України.

Виклад основного матеріалу дослідження. За результатами соціологічного дослідження, проведеного у вересні-жовтні 2019 р., ідентифіковано високий рівень міграційної готовності студентської та учнівської молоді сільських територій Карпатського регіону України щодо працевлаштування, здобуття освіти, постійного місця проживання за кордоном (табл. 1). Загалом, було опитано 1200 студентів випускних курсів та учнів випускних класів із 16 закладів вищої освіти (ЗВО), 18 закладів загальної професійно-технічної освіти (ЗПТО) та 21 закладу загальної середньої освіти (3ЗСО) Львівської, Івано-Франківської, Чернівецької та Закарпатської областей.

Найбільш критичними та загрозливими для подальшого соціальноекономічного розвитку сільських територій Карпатського регіону України тенденціями стали зазначені нижче. Сформувався високий рівень міграційної налаштованості студентської та учнівської молоді. При з'ясуванні, які ж плани має молодь після закінчення навчального закладу, виявилося, що більше 40,0 \% респондентів має намір “їдити на тимчасові заробітки в інші країни”, “продовжити навчання за кордоном”, “виїхати на роботу за кордон на тривалий 
час (більше року)”, або ж “виїхати за кордон на постійне проживання” (табл. 1).

Таблиия 1

Характеристики зовнішньої міграційної активності молоді Карпатського регіону України за групами закладів освіти

\begin{tabular}{|c|c|c|c|}
\hline \multirow{2}{*}{ Запитання / Відповіді } & \multicolumn{3}{|c|}{ Результати відповідей, \% } \\
\hline & $33 \mathrm{CO}$ & ЗПТО & $3 \mathrm{BO}$ \\
\hline \multicolumn{4}{|c|}{ Наміри після закінчення навчального закладу } \\
\hline Працевлаштуватися за спеціальністю & \multirow[t]{11}{*}{ romons } & 37,2 & 48,7 \\
\hline Розпочати власну справу & & 27,4 & 31,1 \\
\hline Продовжити навчатися в Україні & & 31,2 & 21,6 \\
\hline Працевлаштуватися на будь-яку роботу & & 13,0 & 14,8 \\
\hline Виїхати за кордон на постійне проживання & & 10,0 & 14,4 \\
\hline Виїхати на роботу за кордон на тривалий час & & 13,7 & 13,0 \\
\hline Продовжити працювати там, де уже працюю & & 4,5 & 11,3 \\
\hline Продовжити навчання за кордоном & & 7,2 & 10,5 \\
\hline Здобути другу вищу освіту в Україні & & 40,9 & 9,3 \\
\hline Їздити на тимчасові заробітки в інші країни & & 11,0 & 5,6 \\
\hline Інше & & 7,4 & 7,7 \\
\hline \multicolumn{4}{|c|}{ Переваги за наявності вибору } \\
\hline Поїхав би як турист & 30,6 & 32,6 & 35,5 \\
\hline Виїхав би на постійне проживання & 34,1 & 22,1 & 26,1 \\
\hline Виїхав би на кілька років & 15,6 & 18,4 & 17,7 \\
\hline Не виїжджав би за кордон & 7,3 & 9,0 & 10,5 \\
\hline Поїхав би на тимчасові заробітки & 10,2 & 14,9 & 7,8 \\
\hline \multicolumn{4}{|c|}{ Наявність підготовки для реалізації міграційних планів? } \\
\hline Так & 39,6 & 38,4 & 36,1 \\
\hline $\mathrm{Hi}$ & 34,8 & 39,9 & 37,5 \\
\hline Не маю наміру мігрувати & 25,1 & 21,7 & 26,4 \\
\hline \multicolumn{4}{|c|}{ Чинники виїзду за кордон на постійне місце проживання } \\
\hline Низький рівень оплати праці & 52,0 & 50,5 & 50,3 \\
\hline Відсутність роботи в Україні & 41,1 & 35,0 & 29,2 \\
\hline Недостатня можливість професійної реалізації & 28,2 & 24,3 & 29,2 \\
\hline Відсутність стабільності й упевненості в майбутньому & 24,3 & 28,5 & 42,5 \\
\hline Відсутність можливості здобути якісну вищу освіту & 21,0 & - & - \\
\hline Погіршення загальної економічної ситуації в країні & 19,8 & 21,0 & 22,4 \\
\hline Війна & 18,9 & 20,8 & 24,4 \\
\hline Високий рівень корупції & 18,6 & 14,3 & 13,6 \\
\hline Житлові проблеми & 4,3 & 6,5 & 4,7 \\
\hline \multicolumn{4}{|c|}{ Чинники втримання молоді від виїзду за кордон } \\
\hline Високий рівень заробітної плати & \multirow{7}{*}{-} & 78,3 & 86,6 \\
\hline Стабілізація політичної, соціально-економічної ситуації & & 41,1 & 58,3 \\
\hline Наявність постійного місця праці & & 45,1 & 38,8 \\
\hline Можливість ведення бізнесу & & 28,4 & 35,3 \\
\hline Родина, друзі & & 26,7 & 21,2 \\
\hline Високий рівень патріотизму & & 7,7 & 6,6 \\
\hline Нічого не може втримати & & 4,5 & 2,1 \\
\hline
\end{tabular}

Джерело: складено за результатами соціологічного дослідження ДУ “Інститут регіональних досліджень імені М. І. Долішнього НАН України”, проведеного у вересні-жовтні 2019 р. [23]. 
Високі міграційні установки молоді підтверджуються й результатами, одержаними в межах відповідей респондентів на запитання: "Чи виїхали б Ви за кордон, якби була така можливість?”. Сумарний відсоток відповідей “виїхав би на постійне місце проживання”, “виїхав би на кілька років, щоб поліпшити матеріальне становище", “поїхав би на тимчасові заробітки" склав для представників ЗВО 51,6 \%, ЗПТО - 55,4 \% та 33СО - 59,9\%.

Про високий рівень міграційної готовності молоді свідчить і те, що близько 40,0 \% учнів та студентів Карпатського регіону вже здійснювали певну підготовку для реалізації своїх міграційних планів. Це особливо негативно в контексті очікувань до потенційного посилення рівня міграційної активності студентської та учнівської молоді областей Карпатського регіону України. Так, якщо позитивні міграційні установки в сегменті представників ЗВО були виявлені у 51,0 \% опитаних, то підготовку до міграції здійснювали 36,0 \% із них. Отже, йдеться про так звані пороги очікуваної міграції в цьому сегменті молоді, де нижній - 36,0 \% (така частка осіб уже однозначно визначилася щодо свого майбутнього за кордоном), а верхній - 51,0\% (мають позитивні установки). Відповідно, різниця у 15,0 \% є цільовим сегментом молодих осіб, на наміри яких усе ще можуть мати реальний вплив заходи ефективної міграційної політики.

Попри високий рівень міграційних установок молоді, було також виявлено і їх прагнення розпочати власну справу, працевлаштуватися чи продовжити навчатися в Україні. Так, серед планів після закінчення навчального закладу значна частка респондентів обрала варіант "працевлаштуватися за спеціальністю" (48,7 \% представників 3ВО та 37,2 \% - ЗПТО) та “продовжити навчатися в Україні” (41,5\% учнів 33СО). Відмітимо, що розпочати власну справу планує майже третина випускників ЗВО, чверть - ЗПТО та кожен п’ятий учень випускних класів ЗЗСО Карпатського регіону. Цей момент слід урахувати під час розроблення засобів державної політики, орієнтованої на формування економічних стимулів для зайнятості й працевлаштування молоді в Україні.

Нерозв'язаними залишаються проблеми працевлаштування та зберігається низький рівень оплати праці, що є головними можливими причинами виїзду за кордон на постійне місце проживання учнів та студентів. Так, основною причиною, що змусила б молодь виїхати на постійне місце проживання за кордон, є низький рівень оплати праці. Ї̈̈ обрала половина усіх опитаних. Наступною стала відсутність роботи в Україні. На неї вказало 29,2 \% 3ВО, $35,0 \%$ ЗПТО та $41,1 \%$ 33СО; на недостатню можливість професійної реалізації, погані умови праці - 29,2 \%, 24,3 \%, 28,2 \%, відповідно; відсутність стабільності й упевненості в майбутньому - 42,5 \%, 28,5 \%, 24,3 \%, відповідно.

Основними чинниками, що втримали б молодь від виїзду за кордон, $\epsilon$ високий рівень заробітної плати $(86,6 \%$ серед студентів та $78,3 \%$ - учнів ЗПТО), стабілізація політичної та соціально-економічної ситуації в Україні (58,3\% та 41,1\%), наявність постійного місця праці $(38,8 \%$ та 45,1\%), можливість ведення бізнесу (35,3\% та 28,4\%).

Також державним органам регіонального рівня управління не вдається 
зменшити високу частку умовно-потенційних мігрантів серед молоді, що мають наміри мігрувати на постійне місце проживання за кордоном. У сегменті осіб, орієнтованих на стаціонарну міграцію (виїзд на постійне місце проживання), серед представників 3ВО позитивні міграційні установки мали 26,0\% опитаних, iз них 5,0 \% були готовими в найближчий рік мігрувати за кордон, відповідно, частка умовних стаціонарних мігрантів становила 21,0\%. Відповідні показники для представників ЗПТО становили 22,0\%, 5,0 \% та $17,0 \%$, а 33СО - 34,0 \%, 7,0 \% та 27,0 \%. Відмітимо наявність відмінностей у рівнях міграційної активності студентської та учнівської молоді між різними областями Карпатського регіону (табл. 2).

Таблиия 2

Характеристики зовнішньої міграційної активності молоді за областями Карпатського регіону України, \%

\begin{tabular}{|c|c|c|c|c|c|}
\hline \multirow[b]{2}{*}{ Запитання / Відповіді } & \multicolumn{4}{|c|}{ Області } & \multirow{2}{*}{$\begin{array}{c}\text { Карпатський } \\
\text { регіон }\end{array}$} \\
\hline & $\begin{array}{c}\text { Івано- } \\
\text { Франківська }\end{array}$ & Закарпатська & Львівська & Чернівецька & \\
\hline \multicolumn{6}{|c|}{$\begin{array}{c}\text { Наявність планів найближчого року виїзду за кордон } \\
\text { (не враховуючи туристичних поїздок) }\end{array}$} \\
\hline $\begin{array}{l}\text { Так, планую поїхати на } \\
\text { тимчасові заробітки }\end{array}$ & 19,6 & 23,2 & 18,9 & 15,6 & 19,2 \\
\hline $\begin{array}{l}\text { Так, планую поїхати на } \\
\text { роботу на кілька років }\end{array}$ & 17,4 & 10,1 & 8,4 & 7,8 & 10,2 \\
\hline $\begin{array}{l}\text { Так, планую виїхати на } \\
\text { постійне проживання }\end{array}$ & 7,6 & 2,9 & 2,8 & 10,9 & 4,7 \\
\hline $\begin{array}{l}\text { Так, планую поїхати на } \\
\text { навчання }\end{array}$ & 17,4 & 5,8 & 16,4 & 9,4 & 14,3 \\
\hline $\mathrm{Hi}$ & 38,0 & 56,5 & 49,0 & 54,7 & 48,7 \\
\hline \multicolumn{6}{|c|}{ Чинники виїзду за кордон на постійне місце проживання } \\
\hline Відсутність роботи в Україні & 36,6 & 22,5 & 24,3 & 47,7 & 29,2 \\
\hline Низький рівень оплати праці & 55,9 & 53,5 & 45,8 & 58,5 & 50,3 \\
\hline $\begin{array}{l}\text { Недостатня можливість } \\
\text { професійної реалізації, } \\
\text { погані умови праці }\end{array}$ & 28,0 & 23,9 & 31,7 & 26,2 & 29,2 \\
\hline Житлові проблеми & 3,2 & 4,2 & 4,2 & 9,2 & 4,7 \\
\hline $\begin{array}{l}\text { Погіршення загальної } \\
\text { економічної ситуації в країні }\end{array}$ & 19,4 & 18,3 & 23,2 & 27,7 & 22,4 \\
\hline Високий рівень корупції & 16,1 & 16,9 & 13,7 & 6,2 & 13,6 \\
\hline $\begin{array}{l}\text { Відсутність стабільності й } \\
\text { упевненості в майбутньому }\end{array}$ & 40,9 & 52,1 & 41,9 & 36,9 & 42,5 \\
\hline Війна & 22,6 & 23,9 & 26,1 & 20,0 & 24,4 \\
\hline \multicolumn{6}{|c|}{ Наявність підготовки для реалізації міграційних планів } \\
\hline Так & 45 & 38 & 34 & 32 & 36 \\
\hline $\mathrm{Hi}$ & 35 & 41 & 36 & 45 & 38 \\
\hline Не маю наміру мігрувати & 21 & 22 & 30 & 23 & 26 \\
\hline
\end{tabular}




\section{Agricultural and Resource Economics: International Scientific E-Journal}

http://are-journal.com

Зокрема, серед чотирьох областей Карпатського регіону в Закарпатській області зафіксовано найвищий рівень реалізованої міграційної активності молоді, а в Чернівецькій - найнижчий. Так, дев'ять із десяти учнів та студентів Закарпатської області упродовж останніх п'яти років мали досвід перебування за кордоном, тоді як у Чернівецькій області - лише близько 60,0 \%.

Для представників студентської й учнівської молоді Львівської та ІваноФранківської областей міграційні налаштування вищі та вищою була активність за такими аспектами мети поїздки за кордон, як наукові конференції, олімпіади; навчання, практика та стажування; виконання робіт, надання послуг; дрібна комерція.

Студенти Чернівецької області вирізняються найвищим рівнем готовності до стаціонарної зовнішньої міграції. Якщо в середньому по регіону ії̈ виявило $4,7 \%$ респондентів, то в Чернівецькій області - 10,9\%. Планують поїхати на роботу за кордон на кілька років студенти - респонденти з Івано-Франківської області $(17,4 \%$, тоді як у середньому - 10,2 \%). Натомість, намір тимчасових заробітків за кордоном найчастіше виявляють студенти із Закарпатської області $(23,2 \%$ за середнього - $19,2 \%)$.

Можна припустити, що головними причинами вищої схильності до стаціонарної міграції студентської молоді Чернівецької області є труднощі 3 працевлаштуванням. Підтвердженням цьому можуть слугувати відповіді респондентів на запитання “Що саме могло б змусити вас виїхати за кордон на постійне місце проживання?". Так, майже половина респондентів у цій області вказала на відсутність роботи, тоді як у середньому цей показник становив $29,0 \%$ усіх опитаних. Вагомою причиною названо також житлові проблеми (9,2\% за середнього $4,7 \%$.

Івано-Франківську область вирізняє дещо вищий рівень міграційної готовності студентської молоді. Так, 45,0 \% респондентів цього регіону вже здійснювали підготовку для реалізації міграційних планів, тоді як у середньому в Карпатському регіоні цей показник становив $36,0 \%$.

Тривалий час зберігається високий рівень впливу push-чинників середовища міграції, що посилює міграційну активність молоді. Значення інтегральних коефіцієнтів середовища міграційної активності населення (розраховані методом зважування багатомірних величин на основі врахування 30 факторів за групами: демографічна стабільність і стан здоров'я населення, охоплення населення освітніми послугами, стан ринку праці та зайнятості, рівень життя населення, економічний розвиток) для Карпатського регіону за 2005-2018 рр. були істотно вищими в порівнянні із середніми значеннями для України (рис. 1). По-перше, це свідчення більш “агресивного" середовища, яке "виштовхує” населення за кордон; по-друге, у всіх роках аналізованого періоду значення інтегрального індексу для Карпатського регіону перебували в діапазоні критично високого ризику.

Для доведення достовірності отриманих даних, особливо щодо реального впливу досліджуваних умов на рівень міграційної активності населення застосовано кореляційний аналіз (табл. 3). Зокрема, оцінено залежність між 
інтегральним показником середовища “виштовхування" та динамікою виїзду громадян за кордон, яка представлена інструментальною змінною - рівнем міграційної активності населення $\left(Y_{j}\right)$. Результати кореляційного аналізу підтверджують наявність тісного зв'язку між рівнем зовнішньої міграційної активності населення та їі середовищем (коефіцієнт кореляції становить 0,793), а також щільність зв'язку п'яти груп показників (демографічна стабільність і стан здоров'я населення $\left(I_{1 j}\right)$; охоплення населення освітніми послугами $\left(I_{2 j}\right)$; стан ринку праці та зайнятості $\left(I_{3 j}\right)$; рівень життя населення $\left(I_{4 j}\right)$; економічний розвиток країни $\left.\left(I_{5 j}\right)\right)$ та рівня зовнішньої міграційної активності (коефіцієнти кореляції відповідно дорівнювали -0,474; 0,594; 0,440; 0,751; 0,663).

коефіціснт

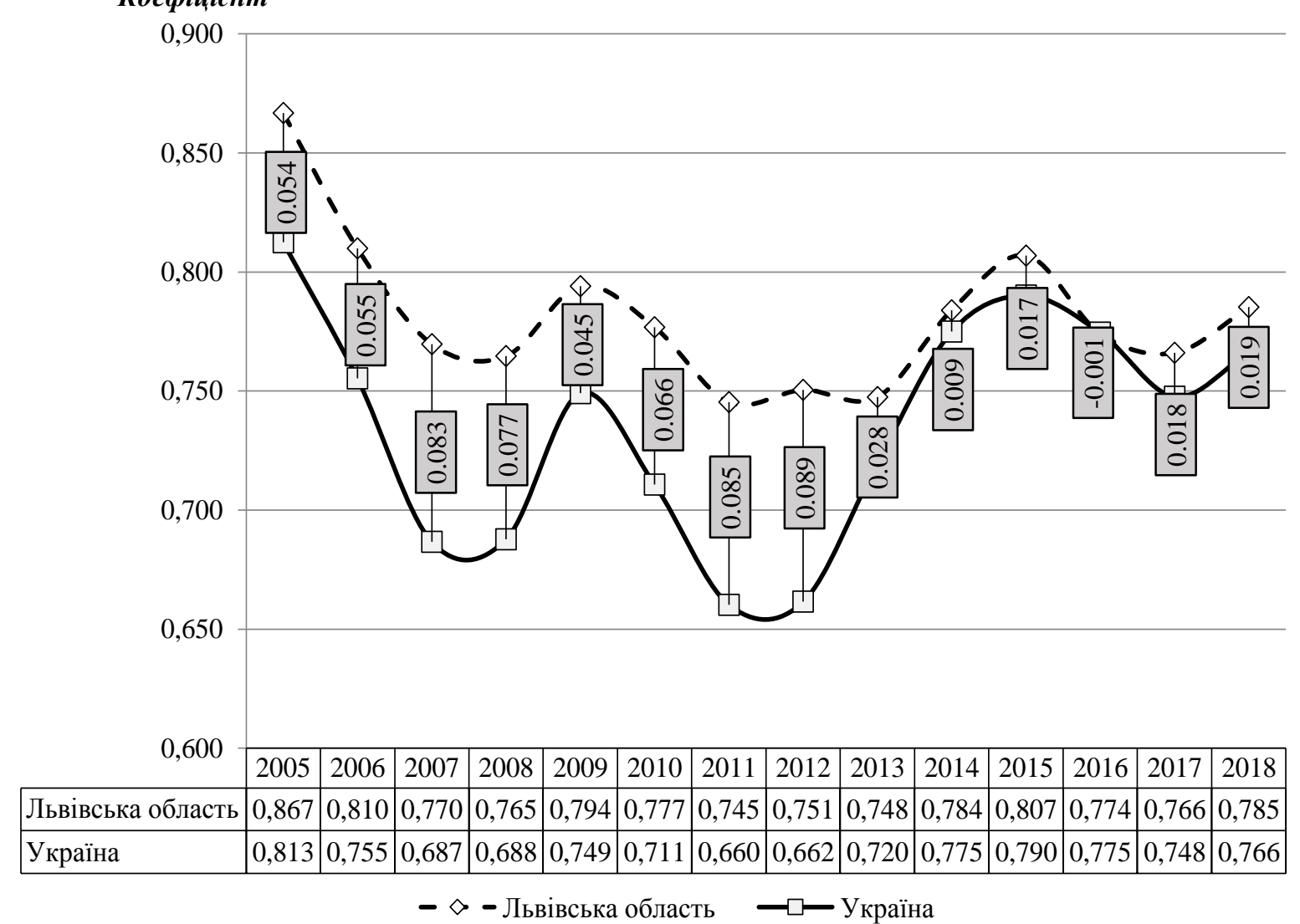

Рис. 1. Середовище міграційної активності населення України

та Львівської області: інтегральні коефіціснти, 2005-2018 рр.

Джерело: побудовано на основі даних Державної служби статистики України [1].

Однозначно таке зростання міграційної активності молоді Карпатського регіону та недостатня керованість розвитку цих процесів зумовлені низкою причин, які тривалий час не вирішуються органами різних рівнів державного управління.

Наразі в регіонах, як і на всій території України, не сформована єдина цілісна система інституційного забезпечення планування міграційної політики, зокрема йдеться про іï недостатнє поширення на регіональний рівень, неврахування особливостей міграційних процесів i пов'язаних iз ними проблемами в специфічних соціально-демографічних групах. 
В Україні чинною залишається Концепція державної міграційної політики [24], реалізуються положення Стратегії державної міграційної політики України на період до 2025 р. [25], прийнято План заходів на 2018-2021 pp. щодо реалізації Стратегії державної міграційної політики України на період до 2025 р. [26]. Проте положення системи стратегічного планування не поширені належним чином на регіональний рівень.

Відсутня Державна програма реалізації міграційної політики в Україні 3 відповідними підпрограмами на регіональному та місцевому рівнях: території 3 особливим характером міграції (обсяги, рівень, темпи нарощування, критичність наслідків), соціально-демографічні групи (учні/студенти, молодь, інтелектуальні кадри, науковці, освітяни, медики), критичні демографічні, суспільні та соціально-економічні загрози, пріоритетні проблеми.

Таблиия 3

Взаємозв'язок середовища “виштовхування" та міграційної активності населення (на прикладі Украйни): кореляційний аналіз

\begin{tabular}{|c|c|c|c|c|c|c|c|c|c|c|}
\hline \multirow{2}{*}{\multicolumn{2}{|c|}{ Показники }} & \multicolumn{8}{|c|}{ Роки } & \multirow{2}{*}{$\mathrm{r}\left(\mathrm{Y}-\mathrm{I}_{\mathrm{nj}}\right)$} \\
\hline & & 2011 & 2012 & 2013 & 2014 & 2015 & 2016 & 2017 & 2018 & \\
\hline \multicolumn{2}{|r|}{$\begin{array}{c}\text { Рівень зовнішньої } \\
\text { міграційної активності, } У\end{array}$} & 0,430 & 0,462 & 0,511 & 0,498 & 0,609 & 0,569 & 0,615 & 0,675 & - \\
\hline \multicolumn{2}{|r|}{$\begin{array}{c}\text { Індекс “виштовхування” } \\
\text { населення за кордон, } I\end{array}$} & 0,660 & 0,662 & 0,720 & 0,775 & 0,790 & 0,775 & 0,748 & 0,766 & $\begin{array}{c}0,793 \\
(0,729 * *)\end{array}$ \\
\hline \multirow{5}{*}{ 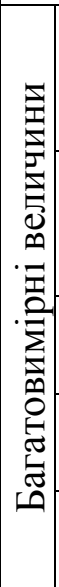 } & $\begin{array}{c}\text { Демографічна } \\
\text { стабільність і стан } \\
\text { здоров'я населення, } I_{1 j}\end{array}$ & 0,940 & 0,968 & 0,951 & 0,931 & 0,913 & 0,963 & 0,928 & 0,942 & $\begin{array}{c}-0,474 \\
\left(0,425^{*}\right)\end{array}$ \\
\hline & $\begin{array}{c}\text { Охоплення населення } \\
\text { освітніми послугами, } \\
I_{2 j}\end{array}$ & 0,234 & 0,335 & 0,817 & 0,607 & 0,600 & 0,600 & 0,607 & 0,616 & $\begin{array}{c}0,594 \\
(0,452 *)\end{array}$ \\
\hline & $\begin{array}{c}\text { Стан ринку праці та } \\
\text { зайнятості, } I_{3 j}\end{array}$ & 0,779 & 0,759 & 0,751 & 0,812 & 0,831 & 0,791 & 0,777 & 0,789 & $\begin{array}{c}0,440 \\
(0,393 *)\end{array}$ \\
\hline & $\begin{array}{l}\text { Рівень життя } \\
\text { населення, } I_{4 j}\end{array}$ & 0,697 & 0,667 & 0,669 & 0,732 & 0,788 & 0,740 & 0,737 & 0,748 & $\begin{array}{c}0,751 \\
(0,643 * *)\end{array}$ \\
\hline & $\begin{array}{c}\text { Економічний розвиток } \\
\text { країни, } I_{5 j}\end{array}$ & 0,530 & 0,504 & 0,497 & 0,761 & 0,766 & 0,749 & 0,668 & 0,678 & $\begin{array}{c}0,663 \\
(0,539 *)\end{array}$ \\
\hline
\end{tabular}

Примітки. 1. Рівень зовнішньої міграційної активності населення розраховано як співвідношення кількості виїздів громадян з України (у найчастіше відвідувані країни: Австралія, Білорусь, Велика Британія, Греція, Єгипет, Ізраїль, Іспанія, Італія, Молдова, Німеччина, ОАЕ, Польща, Росія, Словаччина, Туреччина, Угорщина, Чехія) до загальної кількості населення;

2. Багатовимірні величини ( $\left.I_{\mathrm{n} j}\right)$ - це зважені групові індекси середовища “виштовхування" населення за кордон;

3. У дужках зазначено t-критерій Стьюдента при ${ }^{*} p<0,1 i{ }^{* *} p<0,05$;

4. $\mathrm{r}$ - коефіцієнт кореляції.

Джерело: авторські розрахунки.

Відмітимо й інше, зокрема відсутність програмування міграційної політики на регіональному та місцевому рівні. У Львівській, ІваноФранківській, Закарпатській та Чернівецькій областях не застосовується 
практика розробки та реалізації програмних документів (стратегії, програми, плани заходів) обласного та місцевого рівня, спрямованих на регулювання міграційних процесів. Це є негативним моментом, оскільки неконтрольовані міграційні втрати людського потенціалу дестабілізують функціонування ринку праці, погіршують забезпечення регіональних економік необхідним трудовим потенціалом, відтак, потребують упровадження окремого напряму в системі регіональної політики.

На регіональному рівні не утворено повноцінної ефективної організаційної системи регулювання міграційних процесів. Попри загальне визнання активного збільшення обсягів зовнішньої міграції системною проблемою, загрозою сталого розвитку територій, у системі регіональних органів влади відсутній орган, відповідальний за регіональну політику в цій сфері, а місцеві представництва державної міграційної служби України виконують здебільшого функції щодо надання послуг у сферах громадянства, роботи з іноземцями та особами без громадянства, шукачами притулку, контролю за дотриманням міграційного законодавства, здійснення заходів щодо запобігання та протидії нелегальній міграції. Відтак, на жодну 3 владних структур не покладені завдання ініціювання питань формування та реалізації регіональної міграційної політики, координування дій органів влади, дотичних до тих, чи інших проблем міграції, освітніх послуг, функціонування ринку праці й т. ін.

Також на регіональному рівні не сформовано систему якісного комплексного моніторингу та інформаційно-аналітичного забезпечення обліку й аналізу обсягів, рівня та структурно-динамічних характеристик міграції, а, відтак, належного відстеження та своєчасного виявлення викликів і загроз, прогнозування наслідків зовнішньої міграції населення, особливо найперспективнішої його частини - молоді.

Нині в належній мірі не налагоджено роботу 3 реалізації спільних (передусім із сусідніми країнами та країнами з найбільшими обсягами освітніх і трудових мігрантів із Карпатського регіону) міждержавних, освітніх, науководослідних та бізнес-проєктів, у т. ч. орієнтованих на зміцнення конкурентоспроможності регіональної системи освіти й науки, розвиток нових, зокрема “мобільних", видів освіти й економічної діяльності.

Органи державного управління недостатньо стимулюють економічну активність молоді. До прикладу, проєкт “Доступні кредити 5-7-9 \%” передбачає пільгову відсоткову ставку для кредитування діючих i новостворюваних бізнесів [27]. Його впровадження значною мірою було спрямоване на стимулювання повернення трудових мігрантів, а також на створення сприятливих умов для ведення бізнесу в Україні як альтернативи реалізації міграційних намірів молоді. Проте ця практика ще не набула поширення та не реалізуються програми створення фондів співфінансування витрат зі здобуття освіти, відкриття малого бізнесу, впровадження фінансово-інвестиційних стимулів щодо залучення міграційного капіталу до підприємницької діяльності.

Крім цього, не повною мірою ведеться діяльність щодо формування та 
розвитку елементів інституційної інфраструктури міграційної сфери: функціонування ринку міграційних послуг, використання фінансових ресурсів мігрантів, транскордонної співпраці з урегулювання міграційних процесів.

3 метою усунення зазначених проблемних аспектів i підвищення ефективності регіональної міграційної політики необхідно реалізувати низку інструментів (рис. 3).

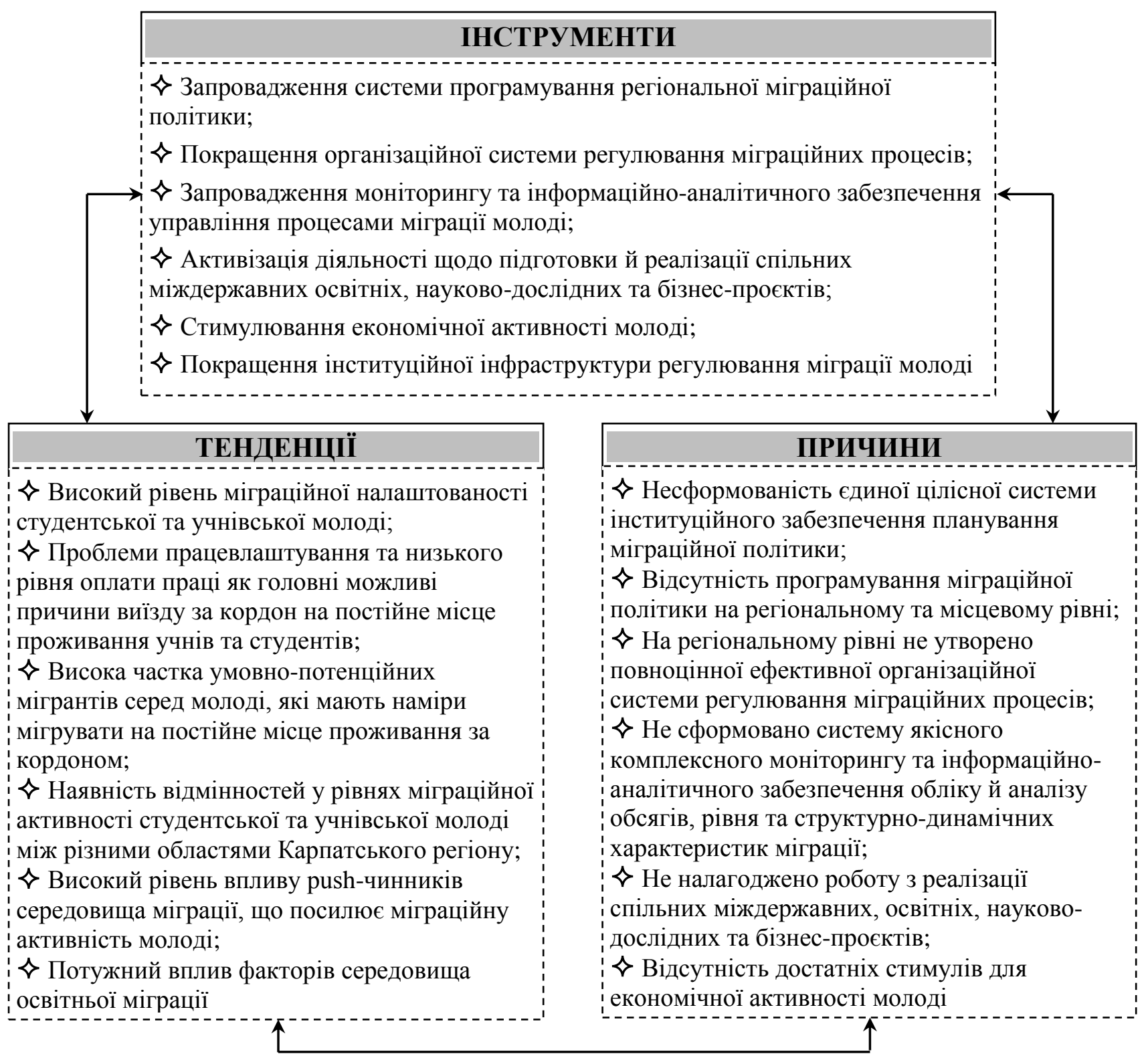

\section{Рис. 3. Інструменти регіональної політики збереження людського ресурсу засобами регулювання зовнішньої міграції молоді сільських територій Карпатського регіону України}

Джерело: авторська розробка.

Зокрема, важливим є запровадження системи програмування регіональної міграційної політики. Для цього можливі дві альтернативи, які не $\epsilon$ взаємовиключними. Перша передбачає ініціювання (перед Кабінетом Міністрів України) розробки Державної програми регулювання міграційних процесів у 
Карпатському регіоні України, де окремими блоками буде врахована проблематика Карпатського регіону з його особливим характером і масштабами міграції та окремих соціально-демографічних груп, насамперед молоді. Така програма необхідна для гармонізації цілей стратегічного та оперативного управління в частині вирішення міграційних проблем Львівської, ІваноФранківської, Закарпатської, Чернівецької областей та України загалом, а також узгодження й координації регулювальних заходів на різних рівнях ієрархії управління; друга - розробку та реалізацію окремих регіональних програм регулювання міграції молоді в Карпатському регіоні. Метою програмування державної регіональної політики $є$ прогнозування та мінімізація негативних наслідків зовнішньої міграції для економіки та суспільства, гарантування ключових компонентів безпеки країни, повніше використання позитивного потенціалу міграції молоді.

Ключовими завданнями, що будуть реалізовані за допомогою програмування, є: облік та аналіз обсягів, рівня й структурно-динамічних характеристик міграції молоді, прогнозування іiі наслідків; формування стимулів до повернення та реінтеграції, навчання та економічної активності на Батьківщині; узгодження стратегічних орієнтирів розвитку економіки та ринку праці 3 міграційними процесами та тенденціями; збереження й ефективне використання людського потенціалу; соціально-економічний захист мігрантів, мінімізація загроз національній безпеці.

Регіональним i місцевим органам влади необхідно також урахувати найбільш проблемні аспекти міграції (особливо молоді), освітньої, інтелектуальної, міграції фахівців, та включати заходи щодо їх вирішення під час прийняття базових регіональних програм: соціально-економічного та культурного розвитку, комплексного розвитку територій, міжнародного й транскордонного співробітництва, освіти та самореалізації молоді, малого й середнього підприємництва, соціальної підтримки окремих категорій громадян, розвитку інформаційного простору та громадянського суспільства.

Потребує покращення організаційна система регулювання міграційних процесів. Реалізація цього інструмента зорієнтована на визначення структури, відповідальної за ініціювання, формування та реалізацію регіональної міграційної політики. Вирішення цього завдання можливе або шляхом розширення функцій регіонального представництва Державної міграційної служби України, або створення регіональних міжвідомчих комісій (при обласних державних адміністраціях) з управління міграційними процесами. Необхідне також активне залучення до організаційної системи управління міграційними процесами молоді закладів освіти та громадських молодіжних організацій, молодіжних центрів праці.

Також важливим $\epsilon$ запровадження моніторингу та інформаційноаналітичного забезпечення управління процесами міграції молоді. Цього можна досягти за рахунок створення інформативно-комунікативного порталу чи інформаційної платформи для комунікації (налагодження спільних досліджень, 
співпраці) з вітчизняними фахівцями, які перебувають за кордоном; створення інтегрованої інформаційно-аналітичної бази даних про зайнятість випускників; надання грантів для досліджень проблем міграції; узгодження діяльності служб статистики, Державної міграційної служби України, громадських та наукових організацій з проблем міграції; проведення періодичних міждержавних аудитів міграційних даних для їх порівняння та верифікації (взаємний аудит).

Необхідно звернути увагу на активізацію діяльності щодо підготовки та реалізації спільних міждержавних освітніх, науково-дослідних та бізнеспроєктів. Першочергово йдеться про співпрацю із сусідніми країнами та країнами, де зафіксовано найбільшу кількість освітніх і трудових мігрантів із Карпатського регіону. У межах реалізації цього інструмента необхідно просувати програми освітнього обміну та реалізації прав на академічну мобільність, спільні навчальні програми на території областей Карпатського регіону України, використати можливості молодіжної громадської активності українських мігрантів за кордоном.

Для реалізації спільних міждержавних освітніх, науково-дослідних та бізнес-проєктів потрібно посилити співпрацю 3 країнами 3 високою концентрацією українських студентів, зокрема в частині захисту їхніх прав, реалізації можливостей і забезпечення механізму їх повернення; здійснювати інформування про іноземні системи освіти та якість навчальних закладів; підтримувати формування бізнес-мереж за участі бізнес-структур з України та закордоном. У межах цього інструмента необхідна реалізація низки заходів щодо зміцнення конкурентоспроможності вітчизняної системи освіти й науки за рахунок узгодження освітніх програм та наукових досліджень із запитами й потребами суб'єктів господарювання, інноваційно-технологічної інфраструктури; розвитку моделей та форм дуальної освіти; упровадження системи грантів для здійснення наукових досліджень.

Важливо також здійснювати регіональні обстеження (створити інтегровану інформаційно-аналітичну базу даних про зайнятість випускників) роботодавців та випускників ЗВО і ЗПТО з метою з'ясування ефективності їх працевлаштування на внутрішньому ринку праці для встановлення відповідності попиту та пропозиції праці, яку забезпечує система освіти, підвищення ефективності реалізації людського потенціалу в Карпатському регіоні й зменшення міграційних втрат; запровадити систематизацію даних обліку траєкторії випускників 33СО для ідентифікації територій із найвищим ризиком міграції учнівської молоді.

Уже тривалий час $є$ необхідність стимулювання економічної активності молоді на теренах Карпатського регіону України. Цьому сприятиме створення фонду співфінансування витрат зі здобуття освіти, відкриття малого бізнесу; упровадження низки фінансово-інвестиційних стимулів щодо залучення міграційного капіталу до підприємницької діяльності в Україні; розвиток інноваційно-технологічної інфраструктури; реалізація програм підтримки молодіжного підприємництва, стартапів; створення на базі ЗПТО та ЗВО 
бізнес-інкубаторів, центрів співпраці бізнесу та науки, високотехнологічних фірм; забезпечення доступу дітей мігрантів до вступу у ЗВО в Україні; стимулювання повернення освітніх мігрантів, у т. ч. інструментом "першого робочого місця".

У межах цього економічного інструмента особливо перспективним за сучасних умов глобалізації та розвитку інформаційної економіки, діджиталізації є підтримка нових, зокрема "мобільних", видів економічної діяльності, розвиток цифрової економіки та "цифрової зайнятості", пропагування ідеї національного економічного патріотизму, підтримка створення високооплачуваних робочих місць у сільській місцевості.

Важливо також ініціювати формування та реалізацію програм створення робочих місць у сільській місцевості шляхом залучення інвестицій, покращення підприємницького середовища, активізації зайнятості в сільських районах та, як наслідок, зниження рівня міграційних прагнень молоді. Необхідно передбачити можливості спрямування коштів мігрантів у реальний сектор економіки для створення нових робочих місць та підвищення ефективності використання міграційного капіталу, залучення ресурсів із програм міжнародних організацій та проєктів міжнародної підтримки для створення сільськогосподарських кооперативів і фермерських господарств (“U-LEAD з Європою”, програми секторальної підтримки СС щодо розвитку сільських територій та ін.).

Звернімо увагу на необхідність покращення інституційної інфраструктури регулювання міграції молоді на сільських територіях. Реалізація цього інструмента орієнтується на створення та розвиток низки елементів інституційної інфраструктури міграції, що покликані мінімізувати іiї ризики та загрози як для осіб, що беруть чи планують брати участь у міграційних процесах, так і для економіки та суспільства. Засобами тут можуть слугувати: формування фонду страхування мігрантів; підтримка проєктів зі створення українських закладів освіти за кордоном, а також розвиток міждержавної співпраці з освітніх обмінів, легального працевлаштування та пенсійного забезпечення учасників міграційних процесів; розвиток інституційної інфраструктури використання фінансових ресурсів мігрантів як інвестиційного ресурсу в місцях постійного проживання їхніх сімей; розробка та реалізація концепції регулювання ринку міграційних послуг, легалізація та ліцензування діяльності наявних неофіційних посередників; укладання двосторонніх міжурядових і міжрегіональних угод з особливим акцентом на забезпеченні гарантій i механізмів стимулювання реінтеграції українців; використання можливостей транскордонного співробітництва із сусідніми країнами ЄС для цілей моніторингу та регулювання міграційних процесів.

Висновки. Для сільських територій областей Карпатського регіону України характерний високий рівень потенційної міграційної активності молоді. При цьому високими залишаються не лише міграційні установки, а й чіткі плани та готовність молоді щодо здійснення міграційного переміщення. Особливо критичними негативними наслідками розвитку означених процесів $є$ : 
- втрата прошарку найбільш креативних осіб молодого працездатного віку; зростання професійно-кваліфікаційних дисбалансів на внутрішньому ринку праці, зокрема через скорочення підготовки, a, відтак, i пропозиції кваліфікованих робітників;

- подальша інституціоналізація міграційних мереж i систем, зокрема освітніх, що сприяють реалізації міграційних намірів молоді;

- зменшення попиту на соціальні послуги, особливо освітні, звуження через це можливостей якісної організації навчального процесу в умовах зовнішньої конкуренції;

- асиметрія розвитку прикордонних територій (у т. ч. залежно від наявності діючого міжнародного пункту пропуску).

Установлено, що головними причинами, які призвели до зростання міграційної активності молоді сільських територій Карпатського регіону, стали недостатня сформованість цілісної системи інституційного забезпечення планування міграційної політики, неналагодженість процесів програмування міграційної політики на всіх рівнях державного регулювання, відсутність повноцінної ефективної організаційної системи регулювання міграційних процесів, низька якість моніторингу й інформаційно-аналітичного управління структурно-динамічними міграційними процесами, неналежна налагодженість міждержавних освітніх, науково-дослідних та бізнес-проєктів, недостатнє стимулювання економічної активності молодого населення.

За таких обставин в Україні повинні відбутися істотні зміни в системі державного регіонального управління міграційними процесами, які прямим чином ураховують особливості міграційних настроїв молоді сільських територій. Так, у Карпатському регіоні важливо запровадити систему програмування, моніторингу, контролю міграційних тенденцій, удосконалити інституційно-організаційні взаємозв'язки між суб'єктами міграційного регулювання, активізувати діяльність щодо підготовки й реалізації спільних міждержавних освітніх, науково-дослідних та бізнес-проєктів, покращити стимулювання економічної активності молоді та відповідну для цього інституціональну інфраструктуру. Реалізація цих інструментів забезпечить підвищення ефективності регіональної політики збереження людського ресурсу, особливо сільських територій Карпатського регіону України.

Перспективним напрямом дальших досліджень $\epsilon$ розробка методики визначення рівня інтенсивності зовнішньої міграції населення 3 урахуванням обсягів «транзитної міграції» у регіоні та моделювання впливу зовнішньої міграції населення сільських територій на соціально-економічний розвиток Карпатського регіону.

\section{Список використаних джерел}

1. Державна служба статистики України. URL: http://www.ukrstat.gov.ua.

2. Inbound internationally mobile students by country of origin. URL: http://uis.unesco.org/indicator/edu-mobility-in-country.

3. Ключковська І., П’ятковська О. Міграційні настрої студентів в умовах 
візової лібералізації (опитування студентів НУ “ЛП” та НТУУ “КПІ”). Львів, 2017. $30 \mathrm{c}$.

4. Лише $6 \%$ студентів, що навчаються у Польщі, планують повернутися в Україну. URL: http://www.polukr.net/uk/blog/2018/11/6vidsotkiv-studentiv-zpolshi-planuyut-povernutsa-v-ukrainu.

5. Boiko V. Diversification of business activity in rural areas as a risk minimization tool of economic security. Management Theory and Studies for Rural Business and Infrastructure Development. 2017. Vol.39. No. 1. Pp. 19-32. https://doi.org/10.15544/mts.2017.02.

6. Ilyash O. Strategic priorities of Ukraine's social security concept development and implementation. Economic Annals-XXI. 2015. No. 7-8(1). Pp. 20-23.

7. Boiko V., Olishchyk P. Tools for ensuring economic security of rural areas development. Scientific Papers Series Management, Economic Engineering in Agriculture and Rural Development. 2019. Vol. 19. Is. 3. Pp. 99-106.

8. Woo Y., Kim E. Analyzing determining factors of young graduates' decision to stay in lagged regions. Sustainability. 2020. No. 12(8). 3094. https://doi.org/10.3390/su12083094.

9. Wenham A. "Wish you were here"? Geographies of exclusion: young people, coastal towns and marginality. Journal of Youth Studies. 2020. No. 23. Pp. 44-60. https://doi.org/10.1080/13676261.2019.1704408.

10. Plotnikova M. Conceptual basis for Ukrainian rural development. Regional Formation and Development Studies. 2015. Vol. 17. No. 3. Pp. 134-144.

11. Borodina O., Rykovskaagro O. Human capital evaluation and capitalisation specific to rural areas of Ukraine. Economic and Regional Studies. 2020. No. 13(1). Pp. 56-59. https://doi.org/10.2478/ers-2020-0005.

12. Ayhana S., Gatskova K., Lehmann H. The impact of non-cognitive skills and risk preferences on rural-to-urban migration in Ukraine. Journal of Comparative Economics. $2020 . \quad$ Vol. 48. $\quad$ Is. 1. $\quad$ Pp. 144-162. https://doi.org/10.1016/j.jce.2019.09.001.

13. Bauernschuster S., Falck O., Heblich S., Suedekum J., Lameli A. Why are educated and risk-loving persons more mobile across regions? Journal of Economic Behavior \& Organization. 2014. No. 98. Pp. 56-69. https://doi.org/10.1016/j.jebo.2013.12.011.

14. Danzer A., Dietz B. Labour migration from eastern Europe and the EU's quest for talents. Journal of Common Market Studies. 2014. No. 52(2). Pp. 183-199. https://doi.org/10.1111/jcms.12087.

15. Gheitarani N., El-Sayed S., Cloutier S., Budruk M., Gibbons L., Khanian M. Investigating the mechanism of place and community impact on quality of life of rural-urban migrants. International Journal of Community Well-Being. 2020. No. 3. Pp. 21-38. https://doi.org/10.1007/s42413-019-00052-8.

16. Levytska O., Mulska O., Ivaniuk U., Kunytska-Iliash M., Vasyltsiv T., Lupak R. Modelling the conditions affecting population migration activity in the Eastern European region: the case of Ukraine. TEM Journal. 2020. Vol. 9. No. 2. 
Pp. 507-514. https://doi.org/10.18421/TEM92-12.

17. Vasyltsiv T. G., Lupak R. L., Kunytska-Iliash M. V. Social Security of Ukraine and the EU: aspects of convergence and improvement of migration policy. Baltic Journal of Economic Studies. 2019. Vol. 5. No. 4. Pp. 50-58. https://doi.org/10.30525/2256-0742/2019-5-4-50-58.

18. Vasyltsiv T., Lupak R., Levytska O. Trends and characteristics of the migration from Ukraine to Poland: the aspect of rural areas and conclusion for state migration policy. Wieś $i$ Rolnictwo. 2020. No. 186(1). Pp. 51-67. https://doi.org/10.7366/wir012020/03.

19. Rosvall P.-A. Counselling to stay or to leave? - Comparing career counselling of young people in rural and urban areas. Compare: A Journal of Comparative and International Education. 2020. No.1. Pp.1-20. https://doi.org/10.1080/03057925.2020.1760788.

20. Wolfe A. W., Black L. W., Welser H. T. Sense of community and migration intentions among rural young professionals. Rural Sociology. 2020. Vol. 85. Is. 1. Pp. 235-257. https://doi.org/10.1111/ruso.12289.

21. Nugin R. Space, place and capitals in rural youth mobility: broadening the focus of rural studies. Sociologia Ruralis. 2020. Vol. 60. Is. 2. Pp. 306-328. https://doi.org/10.1111/soru.12276.

22. Міграція в умовах трансформації регіональних ринків праці України: механізми регулювання; за наук. ред. У. Я. Садової. Львів: ДУ «Інститут регіональних досліджень імені М. І. Долішнього НАН України», 2019. 263 с.

23. Міграційна активність молоді Карпатського регіону України: середовище формування та пріоритети регулювання: матеріали круглого столу 10 грудня 2019 р.; за заг. ред. Т. Г. Васильціва. Львів: ДУ «Інститут регіональних досліджень імені М. І. Долішнього НАН України», 2019. 35 с.

24. Про Концепцію державної міграційної політики: Указ Президента України № 622/2011 від 30.05.2011 p. URL: https://zakon.rada.gov.ua/laws/show/622/2011.

25. Про схвалення Стратегії державної міграційної політики України на період до 2025 року: розпорядження Кабінету Міністрів України № 482-р від 12.07.2017 p. URL: https://zakon.rada.gov.ua/laws/show/482-2017-p.

26. Про затвердження Плану заходів на 2018-2021 роки щодо реалізації Стратегії державної міграційної політики України на період до 2025 року: розпорядження Кабінету Міністрів України № 602-р від 29.08.2018 p. URL: https://zakon.rada.gov.ua/laws/show/602-2018-p.

27. Державна програма “Доступні кредити 5-7-9 \%”. URL: https://5-79.gov.ua.

\section{References}

1. The official site of State Statistics Service of Ukraine (2020), available at: http://www.ukrstat.gov.ua.

2. Inbound internationally mobile students by country of origin (2020), available 
at: http://uis.unesco.org/indicator/edu-mobility-in-country.

3. Klyuchkovskaya, I. and Pyatkovskaya, O. (2017), Migration mood of students in the conditions of visa liberalization (survey of students of NU "LP" and NTUU "KPI"), Lviv, Ukraine.

4. Only $6 \%$ of students studying in Poland plan to return to Ukraine (2020), available at: http://www.polukr.net/uk/blog/2018/11/6vidsotkiv-studentiv-z-polshiplanuyut-povernutsa-v-ukrainu.

5. Boiko, V. (2017), Diversification of business activity in rural areas as a risk minimization tool of economic security. Management Theory and Studies for Rural Business and Infrastructure Development, vol. 39, no. 1, pp. 19-32. https://doi.org/10.15544/mts.2017.02.

6. Ilyash, O. (2015), Strategic priorities of Ukraine's social security concept development and implementation. Economic Annals-XXI, no. 7-8(1), pp. 20-23.

7. Boiko, V. and Olishchyk, P. (2019), Tools for ensuring economic security of rural areas development. Scientific Papers Series Management, Economic Engineering in Agriculture and Rural Development, vol. 19, is. 3, pp. 99-106.

8. Woo, Y. and Kim, E. (2020), Analyzing determining factors of young graduates' decision to stay in lagged regions. Sustainability, no. 12(8), pp. 30-44. https://doi.org/10.3390/su12083094.

9. Wenham, A. (2020), "Wish you were here"? Geographies of exclusion: young people, coastal towns and marginality. Journal of Youth Studies, no. 23, pp. 44-60. https://doi.org/10.1080/13676261.2019.1704408.

10. Plotnikova, M. (2015), Conceptual basis for Ukrainian rural development. Regional Formation and Development Studies, vol. 17, no. 3, pp. 134-144.

11. Borodina, O. and Rykovskaagro, O. (2020), Human capital evaluation and capitalisation specific to rural areas of Ukraine. Economic and Regional Studies, no. 13(1), pp. 56-59. https://doi.org/10.2478/ers-2020-0005.

12. Ayhana, S., Gatskova, K. and Lehmann, H. (2020), The impact of noncognitive skills and risk preferences on rural-to-urban migration in Ukraine. Journal of Comparative Economics, vol. 48, is. 1, pp. 144-162. https://doi.org/10.1016/j.jce.2019.09.001.

13. Bauernschuster, S., Falck, O., Heblich, S., Suedekum, J. and Lameli, A. (2014), Why are educated and risk-loving persons more mobile across regions? Journal of Economic Behavior \& Organization, no. 98, pp. 56-69. https://doi.org/10.1016/j.jebo.2013.12.011.

14. Danzer, A. and Dietz, B. (2014), Labour migration from eastern Europe and the EU's quest for talents. Journal of Common Market Studies, no. 52(2), pp. 183199. https://doi.org/10.1111/jcms.12087.

15. Gheitarani, N., El-Sayed, S., Cloutier, S., Budruk, M., Gibbons, L. and Khanian, M. (2020), Investigating the mechanism of place and community impact on quality of life of rural-urban migrants. International Journal of Community WellBeing, no. 3, pp. 21-38. https://doi.org/10.1007/s42413-019-00052-8.

16. Levytska, O., Mulska, O., Ivaniuk, U., Kunytska-Iliash, M., Vasyltsiv, T. 
and Lupak, R. (2020), Modelling the conditions affecting population migration activity in the Eastern European region: the case of Ukraine. Tem Journal, vol. 9, no. 2, pp. 507-514. https://doi.org/10.18421/TEM92-12.

17. Vasyltsiv, T. G., Lupak, R. L. and Kunytska-Iliash, M. V. (2019), Social security of Ukraine and the EU: aspects of convergence and improvement of migration policy. Baltic Journal of Economic Studies, vol. 5, no. 4, pp. 50-58. https://doi.org/10.30525/2256-0742/2019-5-4-50-58.

18. Vasyltsiv, T., Lupak, R. and Levytska, O. (2020), Trends and characteristics of the migration from Ukraine to Poland: the aspect of rural areas and conclusion for state migration policy. Wieś $i$ Rolnictwo, no. 186(1), pp.51-67. https://doi.org/10.7366/wir012020/03.

19. Rosvall, P.-A. (2020), Counselling to stay or to leave? - Comparing career counselling of young people in rural and urban areas. Compare: A Journal of Comparative and International Education, no. 1, pp.1-20. https://doi.org/10.1080/03057925.2020.1760788.

20. Wolfe, A. W., Black, L. W. and Welser, H. T. (2020), Sense of community and migration intentions among rural young professionals. Rural Sociology, vol. 85, is. 1, pp. 235-257. https://doi.org/10.1111/ruso.12289.

21. Nugin, R. (2020), Space, place and capitals in rural youth mobility: broadening the focus of rural studies. Sociologia Ruralis, vol. 60, is. 2, pp. 306-328. https://doi.org/10.1111/soru.12276.

22. Sadova, U. Ya. ed. (2019), Mihratsiia $v$ umovakh transformatsii rehionalnykh rynkiv pratsi Ukrainy: mekhanizmy rehuliuvannia [Migration in terms of transformation of regional labour markets of Ukraine: mechanisms of regulation], SI "Dolishniy Institute of Regional Research of the National Academy of Sciences of Ukraine", Lviv, Ukraine.

23. Vasyltsiv, T. G. ed. (2019), Mihratsiina aktyvnist molodi Karpatskoho rehionu Ukrainy: seredovyshche formuvannia ta priorytety rehuliuvannia [Migration activity of the youth of the Carpathian region of Ukraine: the environment of formation and priorities of regulation], SI "Dolishniy Institute of Regional Research of the National Academy of Sciences of Ukraine", Lviv, Ukraine.

24. President of Ukraine (2011), Decree of the President of Ukraine "About the concept of the state migration policy", available at: https://zakon.rada.gov.ua/laws/show/622/2011.

25. Cabinet of Ministers of Ukraine (2017), Resolution of the Cabinet of Ministers of Ukraine "About approval of the strategy of the state migration policy of Ukraine for the period till 2025", available at: https://zakon.rada.gov.ua/laws/show/482-2017-p.

26. Cabinet of Ministers of Ukraine (2018), Resolution of the Cabinet of Ministers of Ukraine "About approval of the Action Plan for 2018-2021 for the implementation of the Strategy of State Migration Policy of Ukraine for the period up to 2025", available at: https://zakon.rada.gov.ua/laws/show/602-2018-p.

27. State program "Affordable loans 5-7-9\%", available at: https://5-7-9.gov.ua. 
How to cite this article? Як цитувати цю статтю?

Стиль - ДСТУ:

Васильців Т., Лупак Р., Куницька-Іляш М., Левицька О., Мульска О. Інструменти регіональної політики збереження людського ресурсу засобами регулювання зовнішньої міграції молоді сільських територій Карпатського регіону. Agricultural and Resource Economics. 2020. Vol. 6. No. 3. Pp. 149-170. URL: http://are-journal.com.

Style - Harvard:

Vasyltsiv, T., Lupak, R., Kunytska-Iliash, M., Levytska, O. and Mulska, O. (2020), Instruments of regional policy for human resources conservation by means of regulation of external youth migration of rural territories of the Carpathian region. Agricultural and Resource Economics, vol. 6, no. 3, pp. 149-170, available at: http://are-journal.com. 